\title{
ラット顎下腺アンドロゲンレセプターの 酸性条件での安定性
}

\author{
佐 藤 政 直 \\ 岩手医科大学菌学部口腔生化学講座 (主任 : 太田稔教授)
}

〔受付：昭和62年10月24日〕

\section{Stability of the androgen receptor from rat submandibular gland under acidic conditions}

\author{
Masanao Sato \\ Department of Biochemistry, Iwate Medical University \\ School of Dentistry Chuodori 1-3-27, \\ Morioka, Iwate 020 \\ (Chief: Prof. Minoru Ota) \\ [Accepted for publication: October 24, 1987]
}

Key words: Androgen receptor/submandibular gland/steroid receptor $/ \mathrm{pH} /$ rat

\begin{abstract}
The $\left[{ }^{3} \mathrm{H}\right]$ miborelone $\left(\left[{ }^{3} \mathrm{H}\right] \mathrm{MI}\right)$-binding ability of the androgen receptor (AR) from rat submandibular gland has been studied under acidic conditions. Both in the presence and absence of $10 \mathrm{mM}$ molybdate, the $\left[{ }^{3} \mathrm{H}\right] \mathrm{MI}$-binding ability was decreased as the $\mathrm{pH}$ of the cytosol decreased with the addition of acetic acid and $\mathrm{HCl}$, with pH 5.9 giving $50 \%$ binding. This loss of the binding ability was recovered when the acidic precipitate obtained by centrifugation was dissolved in a buffer at $\mathrm{pH}$ 7.3. In the presence of molybdate, this recovery of the binding clearly correlated with the protein content of the precipitate. In the absence of molybdate, however, the maximum binding recovered in the precipitate was achieved at $\mathrm{pH} 4.9$, and rapidly decreased at lower $\mathrm{pH}$ values ( $1 / 2$ value obtain. ed at $\mathrm{pH} 4.1$ ), even though the protein content in the precipitate was still rather high. When the cytosol was first labeled with $\left[{ }^{3} \mathrm{H}\right] \mathrm{MI}$ and then the $\mathrm{pH}$ was decreased in the absence of molybdate, $\left.{ }^{[} \mathrm{H}\right] \mathrm{MI}$-AR complexes remained unchanged until reaching $\mathrm{pH} 5$ and the amount was then decreased, with $\mathrm{pH} 4.2$ giving $50 \%$ binding. These results indicate that both unoccupied and liganded AR denatures irreversibly at $\mathrm{pH} 4.1-4.2$. On the other hand, in the presence of molybdate, $\left[{ }^{3} \mathrm{H}\right] \mathrm{MI}$-AR com. plexes were more resistent under acidic conditions and a considerable amount of the complexes could still be observed until $\mathrm{pH} 3$. In addition, under acidic conditions in the presence of $0.5 \mathrm{M} \mathrm{KCl}, \mathrm{AR}$ was transformed to a state which could bind to DNA-cellulose. In conclusion, AR from rat submandibular gland exists in a specific state between $\mathrm{pH} 4.1-5.9$; $\mathrm{AR}$ at this state has no ligand-binding ability, but once formed, $\left[{ }^{3} \mathrm{H}\right] \mathrm{MI}-\mathrm{AR}$ complexes do not dissociate. At lower $\mathrm{pH}$ values, AR is transform. ed, and subsequently denatures. Moreover, similar results were obtained from AR from rat prostate, glucocorticoid receptor from rat liver, and estrogen receptor from rat uterus, indicating that these are the common characteristics among these receptors.
\end{abstract}

\section{緒言 \\ マウスやラット頢下腺はアンドロゲン依存性器}

岩手県盛岡市中央通 1-3-27（宁020）

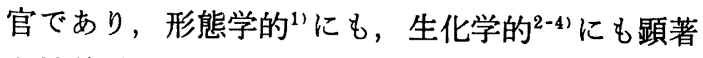
な性差が認められる。アンドロゲンなどの, ステ ロイドホルモンはそれぞれのホルモンの標的臟器 の細胞内に存在するステロイドホルモンレセプタ 
一と結合することによりその作用を発現する゙”。 事実，マウスやラットの細胞質画分にはアンドロ ゲンに特異的で高親和性のアンドロゲンレセプタ 一が存在している ${ }^{6-9)}$ 。アンドロゲンレセプター は雄のみでなく雌の顎下腺にも存在し，その結合 親和性や特異性, ストークス半径, 沈降 係数, DNA-cellulose 結合型へ転換する性質（活性 化）などの物理化学的性質は雄のそれと同一であ

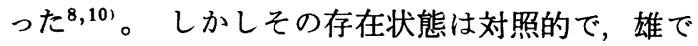
はアンドロゲンレセプターの 70-80\%が 活性型と して核に，雌では非活性型としてほとんどが細胞 質画分に存在していた ${ }^{11)}$ 。この差異は血中のアン ドロゲン濃度に 依存すると考えられた ${ }^{12,13)}$ 。

ところで，一般にタンパク質の構造や機能，ま たこの両者の関係を明らかにするための有力な手 段に, $\mathrm{pH}$ や温度，イオン強度などの条件を変動 させ，種々の生化学的測定をおこなうという方法 がある。ラットやマウスの頢下腺アンドロゲンレ セプターは加温処理や高イオン強度条件 ${ }^{9,14}$ ， 透 析やゲルクロマトグラフィー ${ }^{8,151}$ により活性化さ れる。この際, DNA 結合能の獲得と共に, 分子 量の减少, 表面電荷の変化を伴い, これらの性質 はラット前立腺 ${ }^{(6,17)}$ マウス腎藏(1) やヒト 陰茎部ア ンドロゲンレセプター ${ }^{19)}$ さらに他のステロイドレ セプター20-24) と同様であった。

一方，種々の $\mathrm{pH}$ でのステロイドレセプターの 挙動に関する研究は非常に少ない。しかしながら， ラット肝臓の $\left[{ }^{3} \mathrm{H}\right]$ triamcinolone $\left(\left[{ }^{3} \mathrm{H}\right] \mathrm{TA}\right)-$ グルココルチコイドレセプター 複合体は, $\mathrm{pH} 8$ の条件で活性化されることが知られている ${ }^{25,26) 。}$ また Wilson ${ }^{27)}$ は Dunning tumor のアンドロゲ ンレセプターの沈降係数が $\mathrm{pH} 7-8$ で 7.9S から $6.8 \mathrm{~S}$ まで $\mathrm{pH}$ に依存して変動することを見いだ した。これらの報告はステロイドレセプターが $\mathrm{pH}$ に依存してその性質や分子構造が 変化することを 示唆している。しかしステロイドレセプターの不 安定性のために, これまで $\mathrm{pH}$ の効果についてそ の生化学的性質を詳細に検討した例はない。例え ばラット子宮のエストロゲンレセプターのエスト ラジオール結合能は $\mathrm{pH} 6.5$ より减少し, $\mathrm{pH} 5.8$

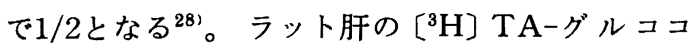
ルチコイドレセプター複合体は $\mathrm{pH} 6-8$ の範囲で
のみ安定であると報告されている ${ }^{25)}$ 。ラット前立 腺アンドロゲンレセプターについてはその結合能 は $\mathrm{pH}$ 6.4-7.5 で最大であり， $\mathrm{pH} 6$ ではほぼ最 大結合の $1 / 2$ に減少する ${ }^{29)}$ 。のように，ステロイ ドレセプターは非常に $\mathrm{pH}$ 変化に対して不安定で あり， $\mathrm{pH} 6$ 以下では変性すると考えられてきた。

最近村山と伊藤 ${ }^{30}$ がブタ子宮のエストロゲンレ セプターの酸性条件でのリガンド結合能について 興味深い報告をしている。エストロゲンレセプタ 一は $\mathrm{pH} 5.5$ 以下では見かけ上リガンド結合能を 示さないが， $\mathrm{pH}$ 5-5.5ではレセプターはリガン ドを結合した状態で沈澱して存在するという。こ の結果から，彼らはエストロゲンレセプターは pH 5-5.5 の領域においても本質的には結合能を 有していると結論した。本報告では，ラット䪽下 腺アンドロゲンレセプターの酸性条件でのリガン ド結合能について検討した。その結果アンドロゲ ンレセプターもこれまで信じられていたほど酸性 条件において不安定ではないことを見いだした。 またこの結果が他の 組織のアンドロゲンレセプタ 一でも，さらに他のステロイドレセプターにも一 般的な現象かどうか検討した。

\section{材料及び方法}

\section{1. 実験材料}

（1）実験動物

8 週齢の Wistar 系ラットを静岡実験動物より 購入し， 14 時間， 10 時間の明暗サイクル，22士 $1{ }^{\circ} \mathrm{C}$ の条件下にて, 固形飼料（オリエンタル酵 母，MF）を与え自由飲水にて飼育した。その後 8-10週齢にて実験に供した。

(2) 試 薬

トリチウム標識合成アンドロゲン,$\left[{ }^{3} \mathrm{H}\right]$ miborelone $\left(7 \alpha, 17 \alpha\right.$-dimethyl $\left[17 \alpha{ }^{-}{ }^{3} \mathrm{H}\right]$-19-nortestosterone, $\left.\left[{ }^{3} \mathrm{H}\right] \mathrm{MI}, 72 \mathrm{Ci} / \mathrm{mmol}\right)$ ，並びに非標識 MI は Amersham より購入した。トリチウム標 識合成グルココルチコイド, $\left[{ }^{3} \mathrm{H}\right]$ triamcinolone acetonide $\left(\left[6,7 \cdot{ }^{3} \mathrm{H}(\mathrm{N})\right]\right.$ triamcinolone acetoni$\left.\mathrm{de},\left[{ }^{3} \mathrm{H}\right] \mathrm{TA}, 37 \mathrm{Ci} / \mathrm{mmol}\right)$, トリチウム標識エス トラジオール $\left[2,4,6,7 \cdot{ }^{3} \mathrm{H}\right]$ estradiol $(99 \mathrm{Ci} /$ $\mathrm{mmol})$ は New England Nuclear より購入し た。Leupeptin はペプチド研より，DNA-cellu- 
loseは和光純薬より購入した。DEAE-cellulose と phosphocellulose は Whatman より, hydroxyapatite (HAP) は生化学工業より購入した。その 他試薬類は特級を用いた。

\section{2. 方法}

(1) 緩衝液

用いた緩衝液は buffer A：50mM Tris- $\mathrm{HCl}$, $1 \mathrm{mM}$ EDTA, $1 \mathrm{mM}$ DTT, $10 \%$ (v/v) glycerol, $\mathrm{pH} 7.3$; buffer B: buffer A K10mM sodium molybdate を含む ; buffer $\mathrm{C}: 10 \mathrm{mM}$ Tris$\mathrm{HCl}, 10 \mathrm{mM}$ sodium molybdate, $0.5 \mathrm{mM}$ DTT, pH 7.3. Fig. 2 の実験については buffer B に $\mathrm{HCl}$ を加え， $\mathrm{pH}$ を 3-8 に調製して使用した。

（2）細胞質の調製と $\left[{ }^{3} \mathrm{H}\right]$ ステロイドによる標識 雌ラットを頸椎脱臼にて屠殺後，水冷した生理 食塩水にて灌流し，顎下腺を摘出し，同食塩水中 にいれた。付着する結合組織を除去後，重量を測 定した。以下の全ての操作，実験は $0-4{ }^{\circ} \mathrm{C} に て$ 行った。組織は 8 倍容の buffer A またはBにて ガラスーテフロンホモジナイザーを用いホモジナ イズした。ホモジネートを $150,000 \times \mathrm{g} 3$ 30分間遠 心し，上清を得た。上清を $1 / 4$ 容の phosphocellulose（あらかじめ buffer A またはBにて平衡化 した後に遠心し，上清を除いた沈澱）とインキュ
ベートし， 10 分後に $1,500 \times \mathrm{g}, 5$ 分の遠心により， 上清を得，これを細胞質とした。

得られた細胞質を $10 \mathrm{nM}\left[{ }^{8} \mathrm{H}\right] \mathrm{MI}$ と 3 時間イ ンキュベートした。その後, 等量の dextran-coated charcoal 㲎濁液 $(0.5 \%$ activated charcoal, $0.1 \%$ dextran T-70を buffer A に䀣濁， DCC) をあらかじめ遠心して得た沈澱と10分間インキュ ベートした後， $1,500 \times \mathrm{g} ， 10$ 分間遠心しすること により遊離のステロイドを除去した。

前立腺アンドロゲンレセプター，肝グルココル チコイドレセプター，子宮エストロゲンレセプタ 一に関する実験では，それぞれ，実験の14-18時間 前に去勢した雄，無傷雄，無傷雌ラットを屠殺し， 肝臟については生理食塩水にて灌流後組織を摘出 し，以下頡下腺と同様に細胞質を調製した。前立 腺アンドロゲンレセプターは $10 \mathrm{nM}\left[{ }^{3} \mathrm{H}\right] \mathrm{MI}$, 肝 臟グルココルチコイドレセプターは $20 \mathrm{nM}\left[{ }^{3} \mathrm{H}\right]$ $\mathrm{TA}$ ，子宮エストロゲンレセプターは $5 \mathrm{nM}\left[{ }^{3} \mathrm{H}\right]$ エストラジオールにより 4-6 時間標識した。

（3）酸性化の条件（Fig. 1)

非標識細胞質，または上記のごとく $\left[{ }^{3} \mathrm{H}\right]$ ステ ロイドにて標識した細胞質を靦拌しながら $\mathrm{pH}$ 7.3 から 5 までは酢酸 $(0.5-2 \mathrm{M})$ を, $\mathrm{pH} 5$ 以下 は塩酸（1-2 M) を一滴づつ加えて $\mathrm{pH}$ を下げ

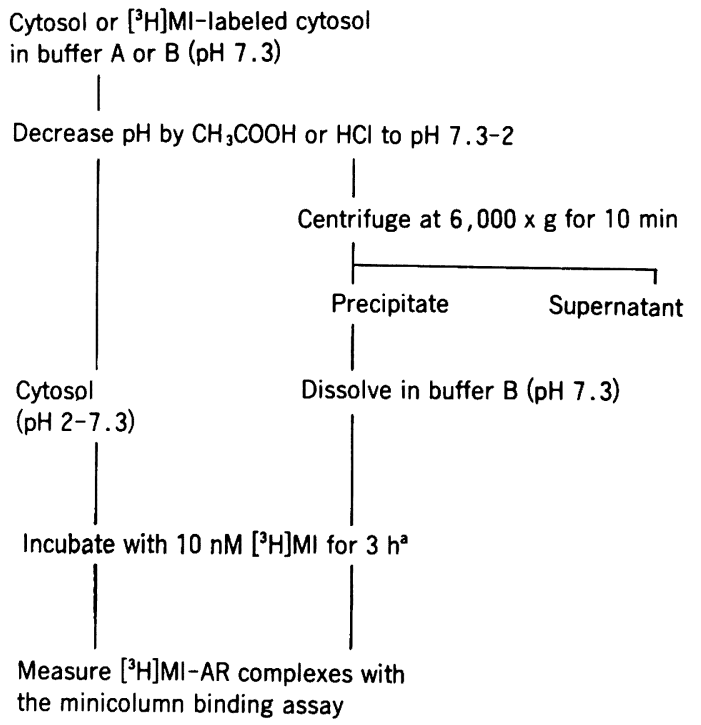

Fig. 1 Outline of acidification of the cytosol. aomitted when the cytosol was originally labeled with $\left[{ }^{8} \mathrm{H}\right] \mathrm{MI}$. 
た。それぞれの $\mathrm{pH}$ においてふた組の酸性化細胞 質 $($ 各 $0.1 \mathrm{~m} l)$ を得た。そのうちの一方は $6,000 \times$ $\mathrm{g}, 10$ 分間遠心し, 得られた沈澱は $0.1 \mathrm{~m} l$ の buffer B (pH 7.3) に溶解した。ただし, 試料が $\mathrm{pH}$ 5 以下の場合には溶解する buffer $\mathrm{B}$ の $\mathrm{pH}$ を 8.2とした。すでに $\left[{ }^{3} \mathrm{H}\right] \mathrm{MI}$ により標識した試料 についてはミニカラム法により結合量とその型を 決定した。一方, 非標識細胞質を酸性化した場合 にはこの後， $\left.{ }^{3} \mathrm{H}\right]$ ステロイドと $3-6$ 時間インキ ュベートしたのちミニカラム法をおこなった。一 部の実験では $\left[{ }^{3} \mathrm{H}\right]$ ステロイドと同時に100倍量 の非標識ステロイドを加え，これを非特異的結合 とした。

(4) ミニカラム法

ミニカラム法は Holbrook らの方法 ${ }^{31}$ を多少改 変9 して行った。すなわち Buffer C に平衡化した $0.25 \mathrm{ml}$ の DNA-cellulose, DEAE-cellulose, HAP をそれぞれ $1 \mathrm{ml}$ のピペットマンチップに つめ，上からこの順に直接 3 個のチップを重㸚た。 $0.1 \mathrm{ml}$ の試料をトップのカラムに重層し, $3 \mathrm{ml}$ の buffer $\mathrm{C}$ で洗浄した。遊離のステロイドは全ての カラムを素通りし，活性化型（transformed-)，非 活性化型 (nontransformed-), 並びにプロテアー ゼにより部分分解されたレセプター（mero-receptor)はそれぞれ DNA-cellulose, DEAE-cellulose, HAP に吸着した。この transformed, nontransformed という用語はこれ以外にそれぞれ activated と nonactivated，または unactivated ともい い, この方が日本語との対応もよいが，これらの 語はステロイドレセプターのリガンドを結合しう る状態と結合しえない状態という意味にも用いら れる。特に本研究では，後で示すようにレセプタ 一が酸性条件下でリガンドを結合しない状態をと りうるので，混同をさけるために英文では transformed, nontransformed とした。各カラムに結 合した $\left[{ }^{3} \mathrm{H}\right]$ ステロイドは $1 \mathrm{ml}$ のエタノールに て溶出しこれにACS-II シンチレーター (Amersham) を添加後，37\%の効率にてその放 射活性を測定した。 $\left[{ }^{3} \mathrm{H}\right]$ ステロイドの総結合量は これら 3 種カラムの結合量の和とした。あるいは HAP カラムのみに試料を添加して，以下同様の 操作をおこない, 直接総結合量を求めた。
（5）高速液体クロマトグラフィー

TSK G4000SW カラム（東洋ソーダ）を用い LKB のシステムにより高速液体クロマトグラフ イーを行なった。カラムを $20 \mathrm{mM}$ sodium phosphate buffer $(\mathrm{pH} 7.3), 10 \mathrm{mM}$ sodium molyb date, $1 \mathrm{mM}$ DTT にて平衡化し, 試料添加後, 同 緩衝液で溶出した。ストークス半径は以下の標準 タンパク質により求めた。Thyroglobulin (8.5 $\mathrm{nm})$, ferritin $(6.1 \mathrm{~nm})$, bovine albumin (3.6 $\mathrm{nm})$, ribonuclease $\mathrm{A}(1.6 \mathrm{~nm})$.

（6）タンパク定量

Bovine albumin を標準とし, Bradford ${ }^{32)} の$ 方 法に従った。通常ラット顎下腺細胞質のタンパク 濃度は約 $4 \mathrm{mg} / \mathrm{m} l$ であった。

\section{結果}

1. 細胞質タンパク質の沈澱と $\left[{ }^{3} \mathrm{H}\right] \mathrm{MI}$ 結合 活性の関倸

これまで各種のクロマトグラフィー法がステロ イドレセプターの分離やその物理化学的性質の検 討のために利用されている。そのほとんどは $\mathrm{pH}$ 7-8の条件で行われており, 広い $\mathrm{pH}$ 領域で DNA-cellulose, DEAE-cellulose, HAP とレセ プターの結合を検討した報告はない。当研究室で はすでに中性条件でのミニカラム法がアンドロゲ ンやグルココルチコイドレセプターのレセプター 型を決定寸るのに非常に簡便な方法であると報告 している ${ }^{91}$ 。そこで本研究では最初に，ミニカラ ム法が酸性 $\mathrm{pH}$ でも $\left[{ }^{3} \mathrm{H}\right] \mathrm{MI}$-アンドロゲンレセ プター複合体とその型の定量に 利用できるかどう かを検討した。顎下腺細胞質を $\left[{ }^{3} \mathrm{H}\right] \mathrm{MI}$ 存在下 で0.3M KCl，一時間活性化処理したのち，DCC 処理を行い $\left[{ }^{3} \mathrm{H}\right] \mathrm{MI}-$ アンドロゲンレセプター複 合体を得，そのうち一定量 $(0.1 \mathrm{~m} l)$ を HAP の みのミニカラムへ添加した。カラムをまず buffer $\mathrm{C}(\mathrm{pH}$ 7.3) で, ついで $\mathrm{pH} 3$ から $\mathrm{pH} 8$ までの 各 buffer でそれぞれ $0.5 \mathrm{ml}$ ゔつ 3 回洗浄した (Fig. 2a)。結果は総結合より非特異的結合を引い た特異的結合であらわした。総結合は $\mathrm{pH} 7$ で最 大で，それ以下の $\mathrm{pH}$, 特に $\mathrm{pH} 6$ から 4 にかけ て減少した。非特異的結合は測定した $\mathrm{pH}$ 範囲で 一定で低值を示すので，特異的結合は総結合と同 

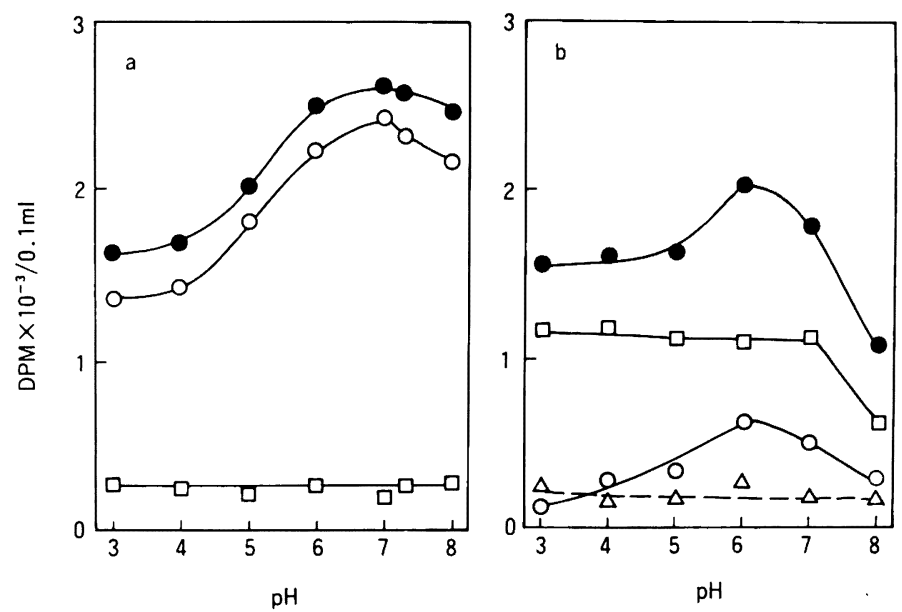

Fig. 2 Binding of $\left[{ }^{3} \mathrm{H}\right] \mathrm{MI} \cdot \mathrm{AR}$ complexes to minicolumns between $\mathrm{pH} 3$ and 8. (a) The cytosol in buffer $\mathrm{A}$ was incubated with $\left[{ }^{3} \mathrm{H}\right] \mathrm{MI}$ for $3 \mathrm{~h}$ in the presence or absence of a 100 -fold molar excess of radioinert $\mathrm{MI}$, and an additional $\mathrm{lh}$ in $0.3 \mathrm{M} \mathrm{KCl}$. After DCC treatment, $0.1 \mathrm{~m} l$ aliquots of $\left[{ }^{3} \mathrm{H}\right]$ MI-labeled cytosol were applied to HAP minicolumns. The columns were washed three times with $0.5 \mathrm{~m} l$ of buffer $\mathrm{C}$, and three times with $0.5 \mathrm{ml}$ of buffer $\mathrm{B}$ adjusted to a $\mathrm{pH}$ ranging between 3 and 8 as indicated. Radioactivity bound to the columns was eluted with $1 \mathrm{~m} l$ of ethanol and counted. Specific bound radioactivity (O) was determined by subtracting the nonspecific bound radioactivity with cold MI ( $\square$ ) from the total bound radioactivity without cold MI (•). (b) The same experiment was performed except that the nonspecific binding was not measured and the samples were analysed by minicolumns with three kinds of resins. Total amount of the binding ( ) was measured as the sum of the bindings of DNA-cellulose (O), DEAE-cellulose $(\square)$ and HAP $(\Delta)$.

様の $\mathrm{pH}$ 依存性を示した。この $\mathrm{pH} 6-4$ におけ る結合量の减少は, 〔 $\left.{ }^{3} \mathrm{H}\right] \mathrm{MI}$-アンドロゲンレセ プター複合体が酸性条件で 不安定なため実際に複 合体量が減少するためか，または複合体は安定だ が，このような $\mathrm{pH}$ 範囲では HAP と複合体の親 和性が減少するためという二つの可能性が考えら れた。そこで同様に処理した標識細胞質を 3 種の 樹脂を重㸚たミニカラムへ添加し以下同様に洗浄 した (Fig. 2b)。

DEAE-cellulose に結合した複合体量は $\mathrm{pH}$ 3-7でほとんど変化しなかったが，DNA-cellu-

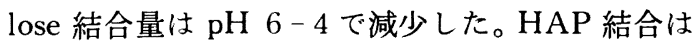
測定した $\mathrm{pH}$ 範囲で一定であった。全体の $\left[{ }^{3} \mathrm{H}\right]$ MI-アンドロゲンレセプター複合体量も $\mathrm{pH}$ 64 では DNA-cellulose 結合量の減少に従い減少 した。DNA-cellulose カラムは三種のミニカラム
のうちトップに位置するので，もし酸性条件にお ける DNA-cellulose 結合の減少が, DNA-cellulose とレセプターの親和性の減少によるなら，引 続き通過するミニカラム，すなわち DEAE-cellulose，または HAP への結合が増加するはずであ る。結果はそのようではなく，むしろ酸性条件で は活性型レセプターが不安定であり，[ $\left.{ }^{3} \mathrm{H}\right] \mathrm{MI}$ が レセプターより解離し, DNA-cellulose 結合が減 少したことを示唆している。この結果はさらに Fig. 2a で見られた HAP 測定による特異的結合 の酸性側での減少も，レセプターとリガンドの解 離, 特に $\left[{ }^{3} \mathrm{H}\right] \mathrm{MI}-$ 活性型レセプターの解離によ ることを示している。それゆえにこれらの結果よ

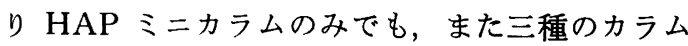
を重ねたミニカラム法でも，中性条件のみでなく 酸性条件でも [ $\left.{ }^{3} \mathrm{H}\right] \mathrm{MI}$-アンドロゲンレセプター 

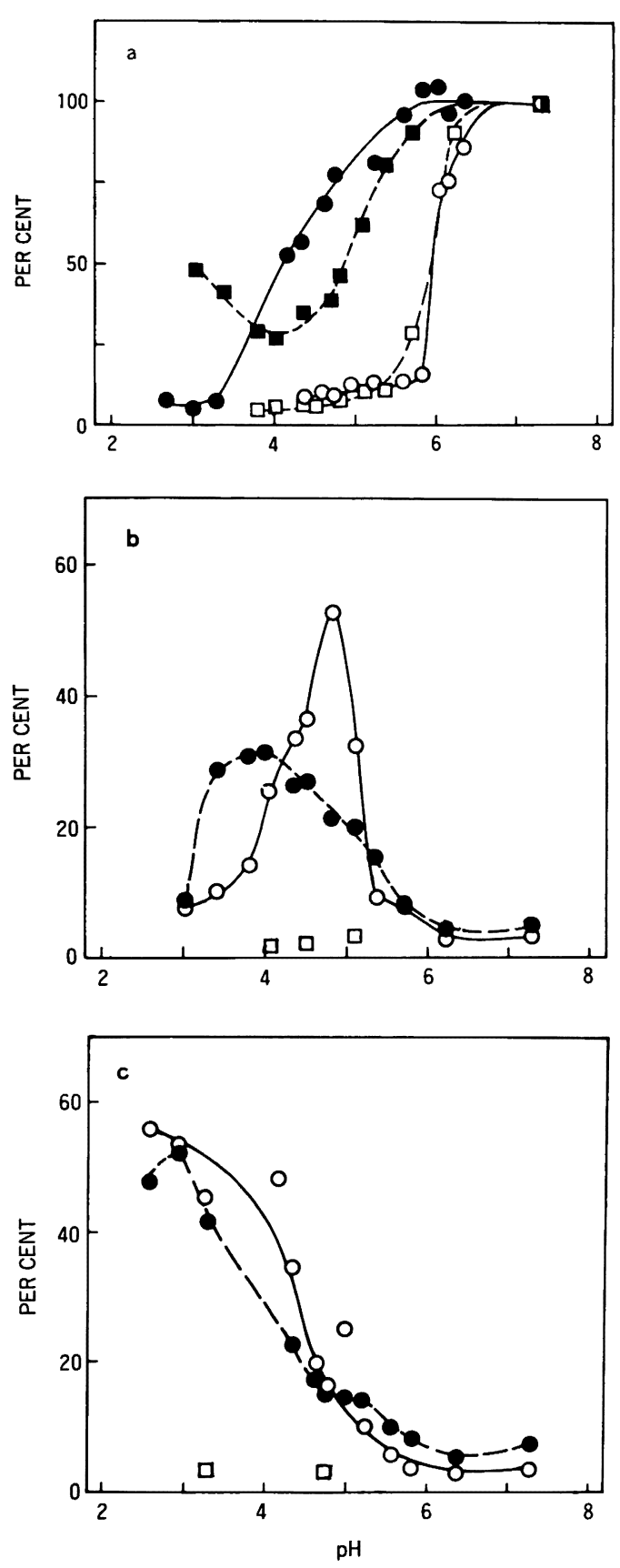

複合体を定量的に測定しうると結論した。また以 下の実験ではミニカラムに添加する酸性 $\mathrm{pH}$ のサ ンプル量は $0.1 \mathrm{~m} l$ であり, 洗浄は $\mathrm{pH} 7.3$ の緩衝 液でおこなったので，ミニカラム法実施中の活性 型 $\left[{ }^{3} \mathrm{H}\right] \mathrm{MI}$-アンドロゲンレセプター複合体の解 離には非常に少ないものと考えられる。またこれ
Fig. 3 Relationship between precipitation of cytosolic proteins and $\left[{ }^{3} \mathrm{H}\right]$ MI-binding ability of the acidified cytosol. Acid solutions were added to the cytosol in buffer A or B with stirring, to decrease the $\mathrm{pH}$ as described in Fig. 1. Two aliquots $(0.1 \mathrm{~m} l$ each) were withdrawn from the acidified cytosol at each $\mathrm{pH}$, as indicated. A series of samples were centrifuged at $6,000 \times \mathrm{g}$ for $10 \mathrm{~min}$ and the supernatants and the precipitates were separated. $(a)$ The acidified cytosol in buffer A ( $\square$ ) or $\mathrm{B}(\mathrm{O})$ at every $\mathrm{pH}$ value as indicated was incubated with ${ }^{3} \mathrm{H}$, MI for 3 h and the total binding was measured by a HAP minicolum. The protein concentration of the supernatant of the acidic cytosol in buffer A ( $)$ or B (•) was determined. $(b$ and $c$ ) The precipitate obtained from acidic cytosol in buffer $\mathrm{A}(b)$ or B (c) was dissolved in the original volume $(0.1 \mathrm{~m} l)$ of buffer $B$, and then, the protein concentration $(\bullet)$ and $\left[{ }^{3} \mathrm{H}\right]$ MI-binding (O) were determined. At several $\mathrm{pH}$ values, the samples were incubated with $\left[{ }^{3} \mathrm{H}\right] \mathrm{MI}$ in the presence of a 100 -fold molar excess of radioinert MI ( $\square)$. Results are indicated as per cent of the original cytosol in buffer A and B. Total bindings of original cytosols in buffer $\mathrm{A}$ and $B$ were 2444 and $3463 \mathrm{dpm} / 0.1 \mathrm{ml}$, respectively.

らの結果は酸性条件でも $\left.{ }^{3} \mathrm{H}\right] \mathrm{MI}$-アンドロゲン レセプター複合体がすみやかに変性するものでは ないこと，特に非活性型の $\left[{ }^{3} \mathrm{H}\right] \mathrm{MI}$ なアンドロゲ ンレセプター複合体はかなり安定であることを示 唆している。さらに $\left[{ }^{3} \mathrm{H}\right] \mathrm{MI}$ 非特異的結合は総 結合の $1 / 10$ 程度であり，その量は酸性条件でも増 
加寸ることはなかったので，以下の実験では特に 記述しないかぎり非特異的結合を測定せず，結果 は総結合で示した。

つぎに酸性条件での䕘下腺細胞質タンパク質の 沈澱とアンドロゲンレセプターの $\left[{ }^{3} \mathrm{H}\right] \mathrm{MI}$ 結合 能の関係について検討した。Fig. 3a に示したよ うに上清のタンパク質量は $\mathrm{pH} 6$ 付近から減少し 始めた。その経過は10mM sodium molybdate の 有無によりやや異なり, pH 6-4 では molybdate 存在下でやや上清のタンパク量は多かった。 $\mathrm{pH} 4$ 以下では molybdate 存在下では上清のタンパク 量はさらに減少するのに対し，非存在下では上清 のタンパク質量は $\mathrm{pH} 4$ で最小で以下増加した。 一方細胞質の $\left[{ }^{3} \mathrm{H}\right] \mathrm{MI}$ 結合能は酸性条件で急速 に減少した。すなわち molybdate の有無に関わら

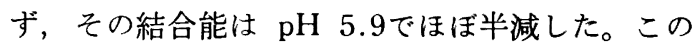
$\mathrm{pH}$ では細胞質タンパク質はまだほとんど沈澱し ていない。このことは酸性条件でのレセプターの [ $\left.{ }^{3} \mathrm{H}\right] \mathrm{MI}$ 結合能の吉失が細胞質タンパク質の酸 沈澱とは無関係の現象であることを示している。 またタンパク質の沈港する経過が molybdate の 有無で異なるのに対し, 結合能の减少は molybdate の存否に依存しないこともこれを支持する。 $\mathrm{pH} \quad 6$ 付近でみられるこのリガンド結合能の減少 からこれまで一般にアンドロゲンレセプターやさ らに他のステロイドレセプターは酸性条件で非常 に不安定であると考えられてきたように思われ る。ところが，酸沈澱したタンパク質を，再び $\mathrm{pH} 7.3$ 緩衝液に溶解し, $\left[{ }^{3} \mathrm{H}\right] \mathrm{MI}$ とインキュ ベーションすると, $\left[{ }^{3} \mathrm{H}\right] \mathrm{MI}$ の結合が検出された (Fig. $3 b$ and c)。非特異的結合はこれらの条件で 常にわずかであった（四角で示す）。特に molybdate 存在下では $\left[{ }^{3} \mathrm{H}\right] \mathrm{MI}$ 結合能は沈澱するタン パク量に依存し, 一度 $\mathrm{pH} 3$ 以下の酸性条件にさ らされた後でも $\mathrm{pH}$ を中性に戻すことより結合能 を回復した。つまり $\mathrm{pH}$ 5.9でのアンドロゲンレ セプターの $\left[{ }^{3} \mathrm{H}\right] \mathrm{MI}$ 結合能の堒失は可逆的で あることを示している。一方, molybdate を含ま ない条件で細胞質を酸性化すると，沈澱するタン パク量は $\mathrm{pH} 4$ まで増加しつゔけるにもかかわら す，沈澱より回収される $\left[{ }^{3} \mathrm{H}\right] \mathrm{MI}$ 結合は $\mathrm{pH}$ $4.9 \pm 0.1 （ \mathrm{n}=4)$ にて最大となり, 以下減少し
た。これは $\mathrm{pH}$ 4.9以下でレセプターの不可逆的 変性が起こるためではないかと考えられた。また $\mathrm{pH} \quad 4.5-5$ の範囲の結合は沈澱するタンパク量に 比へ，高い值を示したが，これについては後で検 討する。このように, pH 6でのレセプター結合 能の捛失は molybdate 非依存性であるのに対 し，pH 4.9以下の酸沈澱に見いだされる結合活性 の回復は molybdate に依存する現象であること が明らかとなった。

2. 酸性条件にて沈溊する $\left[{ }^{3} \mathrm{H}\right] \mathrm{MI}$ 結合能の 性質

Molybdate 存在下, $\mathrm{pH} 4.0$ にて沈澱する細胞質 タンパク質を buffer B に再溶解したのち, $\left[{ }^{3} \mathrm{H}\right]$ MI とインキュベーションした試料を TSK G $4000 S W$ に添加しゲルクロマトグラフィーを行 った。Fig. 4 に示すように, Fraction 27付近に特 異的 $\left[{ }^{3} \mathrm{H}\right] \mathrm{MI}$ 結合のピークが得られた。この位 置は細胞質を $\left[{ }^{3} \mathrm{H}\right] \mathrm{MI}$ にてラベルして得られる 位置とほとんど同位置で，その Stokes 半径は 8.1nm であった。Fraction 42付近のピークは遊 離の $\left[{ }^{3} \mathrm{H}\right] \mathrm{MI}$ であった。Molybdate 非存在下で $\mathrm{pH} 5.0$ ，または molybdate 存在下 $\mathrm{pH} 4.0$ の条件 で沈澱し，再溶解により回復する $\left[{ }^{3} \mathrm{H}\right] \mathrm{MI}$ 結合 のそれぞれ86\%，90\%は DEAE-cellulose 結合型 であった（Table 1)。これらの結果は，酸性条件 で沈澱し再溶解によって得られた $\left[{ }^{3} \mathrm{H}\right] \mathrm{MI}$ 結合 が，細胞質のそれと同様の，いわゆる非活性型レ セプターであることを示している。

3. 酸性条件における $\left[{ }^{3} \mathrm{H}\right] \mathrm{MI}$-アンドロゲン レセプター複合体の安定性

次に Fig. 2 の実験と逆に細胞質をあらかじめ [ $\left.{ }^{3} \mathrm{H}\right] \mathrm{MI}$ により標識し, $\left[{ }^{3} \mathrm{H}\right] \mathrm{MI}-$ アンドロゲン レセプター複合体を得, その後に細胞質の $\mathrm{pH}$ を 下げ，アンドロゲンレセプターがすでに結合して いる $\left[{ }^{3} \mathrm{H}\right] \mathrm{MI}$ の保持能力について検討した。酸 性条件での $\left[{ }^{3} \mathrm{H}\right] \mathrm{MI}$ 結合能を測定した害験 （Fig. 3a）と条件を合わせるために各 $\mathrm{pH} に て 3$ 時 間放置した後に, 残存する $\left[{ }^{3} \mathrm{H}\right] \mathrm{MI}$-アンドロゲ ンレセプター複合体量を HAP ミニカラム法によ り測定した (Fig. 5)。本条件では Fig. 3a で見 られたような $\mathrm{pH}$ 5.9での結合能の減少はなく， より低い $\mathrm{pH}$ 条件でもかなりの量の複合体が残っ 


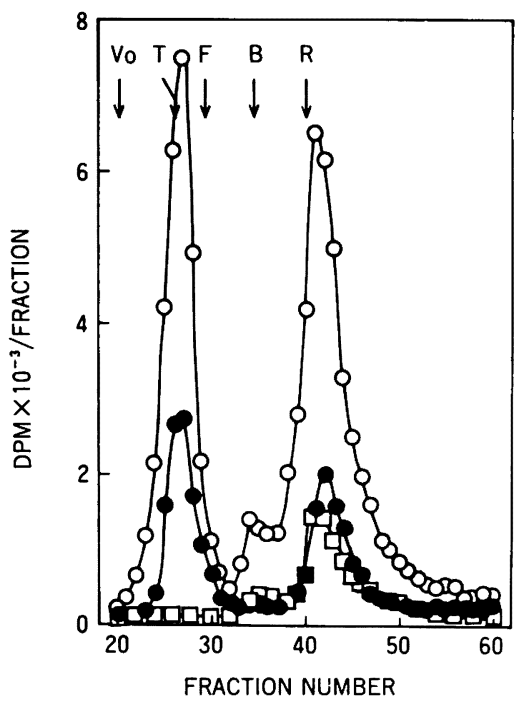

Fig. 4 Gel chromatography of the acidic precipitate. The precipitate obtained from the acidic cytosol at $\mathrm{pH} 4.0$ in buffer $\mathrm{B}$ was dissolved in the original volume of buffer $B$ and incubated with $\left[{ }^{3} \mathrm{H}\right] \mathrm{MI}$ in the presence ( $\square$ ) or absence ( $)$ of a 100 -fold molar excess of radioinert MI. After DCC treatment, $1 \mathrm{~m} l$ of the sample was loaded onto a TSK G4000SW column equilibrated in $20 \mathrm{mM}$ sodium phosphate buffer ( $\mathrm{pH} \mathrm{7.3)}$ containing $10 \mathrm{mM}$ molybdate and $0.5 \mathrm{mM}$ DTT. As a control, $1 \mathrm{~m} l$ of $\left[{ }^{3} \mathrm{H}\right] \mathrm{MI}$-labeled cytosol in buffer $B$ was loaded onto the column (O). The flow rate was $0.5 \mathrm{~m} l / \mathrm{min}$ and 0.75 $\mathrm{m} l$ of the fractions were collected and counted for radioactivity. Stokes radii were estimated using the following standard : blue dextran $2000\left(\mathrm{~V}_{0}\right.$, void volume), thyroglobulin $(T, 8.5 \mathrm{~nm})$, ferritin (F, 6.1nm), bovine albumin ( $B, 3.6$ $\mathrm{nm})$, and ribonuclease $A(R, 1.6 \mathrm{~nm})$.

た。また複合体量の減少は molybdate 依存性で あった。すなわち molybdate 非存在下では $\mathrm{pH}$ $4.1 \pm 0.1 （ \mathrm{n}=4)$ で複合体量は $1 / 2$ となり，molybdate 存在下では，複合体はさらに低い $\mathrm{pH}$ ま で安定であった。またこの試料を遠心すると, 沈

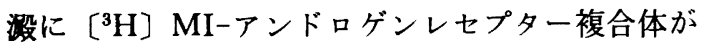

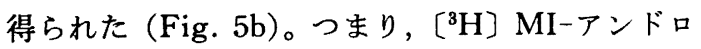
ゲンレセプター複合体は，酸性条件で解離するこ となく沈涮することを示している。また molybdate 非存在下で pH 5 付近より観察される複合体

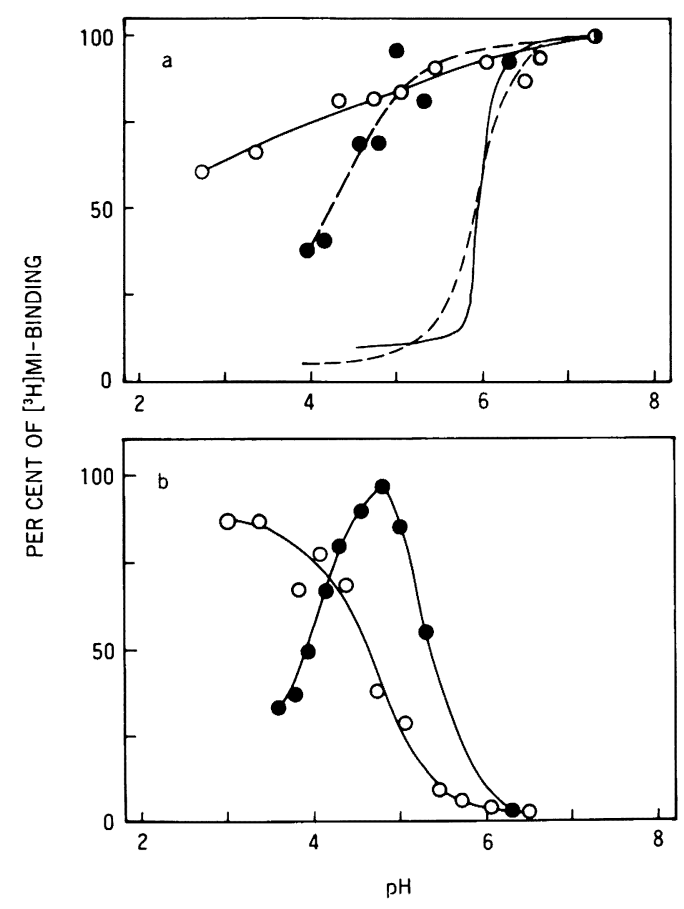

Fig. 5 Stability and precipitation of $\left[{ }^{3} \mathrm{H}\right] \mathrm{MI}-\mathrm{AR}$ complexes under acidic conditions. The cytosol in buffer $\mathrm{A}$ or $\mathrm{B}$ was incubated with $\left[{ }^{3} \mathrm{H}\right] \mathrm{MI}$ for $3 \mathrm{~h}$, treated with DCC, and acidified at various $\mathrm{pH}$ values as indicated. (a) After being kept for $3 \mathrm{~h}$ at each $\mathrm{pH}$ level, $0.1 \mathrm{~m} l$ of the sample in buffer A ( ) or B (O) was applied to a HAP minicolumn. As a control, results in Fig. 2a on the binding of the cytosol in buffer A (dotted line) and B (line) are depicted. (b) After $3 \mathrm{~h}$ of acidification, the precipitate was obtained by centrifugation from the acidified cytosol in buffer A ( ) or B (O), dissolved in 0.1 $\mathrm{m} l$ of buffer $\mathrm{B}$, and applied to a HAP minicolumn. Results are indicated as per cent of the $\left[{ }^{3} \mathrm{H}\right]$ MI-binding to that of the original cytosol in buffer $A(1,377$ $\mathrm{dpm} / 0.1 \mathrm{~m} l)$ and $B(3,654 \mathrm{dpm} / 0.1 \mathrm{~m} l)$.

量の減少が, molybdate により抑制されたが, こ れは Fig. 3b, c で観察されたリガンド結合能の不 可逆変性過程とよく一致する。この一致はアンド ロゲンレセプターがリガンドの結合に依存せず に，その $1 / 2 か ゙ ~ p H ~ 4.1$ 付近で変性することを強く 示唆する。

4. 酸性条件でのアンドロゲンレセプターの活 
Table 1 Minicolumn binding assay of the precipitate of acidic cytosol

\begin{tabular}{lcccc}
\hline & Molybdate & $\begin{array}{c}\text { Total bound } \\
\text { dpm (per cent) }\end{array}$ & $\begin{array}{c}\text { DNA-cellulose } \\
\text { bound } \\
\text { dpm (per cent) }\end{array}$ & $\begin{array}{c}\text { DEAE-cellulose } \\
\text { bound } \\
\text { dpm (per cent) }\end{array}$ \\
\hline Cytosol & - & $4347(100)$ & $304(7)$ & $4043(93)$ \\
Precipitate (pH 5.0) & - & $2149(100)$ & $293(14)$ & $1856(86)$ \\
Cytosol & + & $1072(100)$ & $61(6)$ & $1011(94)$ \\
Precipitate (pH 4.0) & + & $963(100)$ & $98(10)$ & $865(90)$ \\
\hline
\end{tabular}

The cytosol in buffer $\mathrm{A}$ or $\mathrm{B}$ was acidified to $\mathrm{pH} 5.0$ and 4.0 , respectively, and was centrifuged at $6,000 \times \mathrm{g}$ for $10 \mathrm{~min}$. The precipitate obtained was dissolved in the original volume of buffer $\mathrm{B}$ and $0.1 \mathrm{~m} l$ aliquot was incubated with $\left[{ }^{3} \mathrm{H}\right] \mathrm{MI}$ for $3 \mathrm{~h}$. As a control, the cytosol in buffer $A$ or $B$ was incubated with $\left[{ }^{3} \mathrm{H}\right] \mathrm{MI}$ and all samples were assayed by minicolumns of DNA-cellulose and DEAE-cellulose. A HAP column was omitted because its binding was low (data not shown). Total binding was estimated as the sum of DNA-cellulose and DEAE-cellulose bound. Results are indicated as both radioactivity bound and per cent of the binding to the total bound for each sample.

性化

前章で $\mathrm{pH}$ 4.9以下特に4.1付近でのアンドロゲ ンレセプターの失活が molybdate に依存するこ とを示した。また Fig. 2b の結果は酸性条件で活 性型アンドロゲンレセプターが非活性型より失活 しやすいことを示唆していた。すでによく知られ ているように molybdate は最も強力なステロイ ドレセプターの活性化阻害剤である ${ }^{33-35) 。 そ こ て ゙ ~}$ 酸性条件でのアンドロゲンレセプターの不可逆的 変性がレセプターの活性化と関連する可能性が考 えられたので以下の実験を行った。Fig. と同様に 細胞質をあらかじめ $\left[{ }^{3} \mathrm{H}\right] \mathrm{MI} に よ り$ 標識し，以 下酸性化を行った。沈澱の $\left[{ }^{3} \mathrm{H}\right] \mathrm{MI}$-アンドロゲ ンレセプター複合体はほとんど DEAE-cellulose に結合する非活性型レセプターであった。しかし ながら, pH 5 以下では常に少量の DNA-cellulose 結合がみられた (Fig. 6)。各 $\mathrm{pH}$ での活性型 レセプターの量は増加することはなかったが，そ の総結合に占める割合は $\mathrm{pH} 5$ 以下上昇し, $\mathrm{pH}$ 4.0 で40\%であった。 $\mathrm{pH} 5.6$ と6でも高い割合が 得られたが, この場合はほとんど複合体が沈澱し ていないためと思われる。このことは $\mathrm{pH} 5$ 以下 の $\left[{ }^{3} \mathrm{H}\right] \mathrm{MI}$-アンドロゲンレセプター複合体の減 少は，レセプターの活性化とそれにつづく変性に よって説明しうることを示唆する。しかしなが ら，非活性型レセプターが，活性型とはならず， 直接変性するとしても，この現象を矛盾せずに説

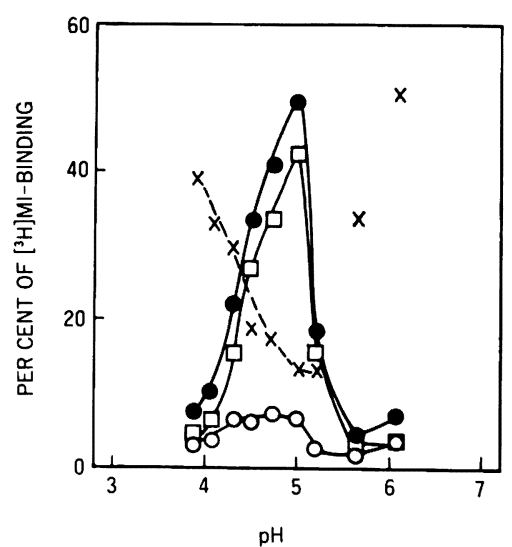

Fig. 6 DNA-binding ability of the acidic precipitate. The $\mathrm{pH}$ of the cytosol in buffer A was decreased and $0.1 \mathrm{~m} l$ aliquot was obtained at each $\mathrm{pH}$ level as indicated. The acidified cytosol was centrifuged and the precpitate obtained was dissolved in $0.1 \mathrm{~m} l$ of buffer $B$, and incubated with $\left[{ }^{3} \mathrm{H}\right] \mathrm{MI}$. After $3 \mathrm{~h}$, the sample was applied to minicolumns with DNA-cellulose (O) and DEAE-cellulose ( $\square$ ). A HAP column was omitted because the binding was low (data not shown). Total bound radioactivity (O) was obtained as the sum of the bindings to DNA-cellulose and DEAE-cellulose. Results are indicated as per cent of the total binding of the original cytosol $(4,347 \mathrm{dpm} / 0.1 \mathrm{ml})$. Cross marks indicate per cent of DNAcellulose bound to the total bound at each $\mathrm{pH}$ value. 
佐藤政㨁：ラット額下腺アンドロゲンレセプターの酸性条作での安定性

Table 2 Transformation of androgen reacptor in the presence of $0.5 \mathrm{M} \mathrm{KCl}$ under acidic conditions

\begin{tabular}{|c|c|c|c|c|c|}
\hline & Treatment & Total bound & $\begin{array}{l}\text { DNA-cellulose } \\
\text { bound } \\
\text { dpm (per cent) }\end{array}$ & $\begin{array}{l}\text { DEAE-cellulose } \\
\text { bound }\end{array}$ & HAP bound \\
\hline \multirow[t]{3}{*}{ Cytosol } & - & $3100(100)$ & 411 (13) & $2464(80)$ & $225(7)$ \\
\hline & $0.5 \mathrm{M} \mathrm{KCl}$ & $3202(100)$ & $990(31)$ & $1997(62)$ & $215(7)$ \\
\hline & $\begin{array}{l}0.5 \mathrm{M} \mathrm{KCl} \\
\rightarrow \mathrm{pH} 3.0\end{array}$ & $3139(100)$ & $2156(69)$ & $721 \quad(23)$ & $262(8)$ \\
\hline Precipitate & $\begin{array}{l}0.5 \mathrm{M} \mathrm{KCl} \\
\rightarrow \text { pH } 3.0 \\
\rightarrow \text { centrifuge }\end{array}$ & $1578(100)$ & $1031(65)$ & $462(29)$ & $84(5)$ \\
\hline
\end{tabular}

The cytosol in buffer A was incubated with $\left[{ }^{3} \mathrm{H}\right]$ MI for $3 \mathrm{~h}$ and further incubated with $0.5 \mathrm{M}$ $\mathrm{KCl}$. After $\mathrm{lh}$, free steroid was removed by the DCC method and the cytosol was acidified to $\mathrm{pH} 3.0$. The acidic cytosol was centrifuged and the precipitate obtained was dissolved in the original volume of buffer B. Thereafter, an aliquot $(0.1 \mathrm{~m} l)$ of the sample at each step was applied to the minicolumn and counted. Results are indicated as both radioactivity bound and per cent of the binding of each column to total bound radioactivity in each sample.

明できると考えられるので，この実験からは明確 な結果が得られなかった。

ところで，ある種類のタンパク質は酸性条件で 塩の共存により安定化することが知られている。 アンドロゲンレセプターも molybdate 非存在, $0.5 \mathrm{M} \mathrm{KCl}$ 存在下で, より低い $\mathrm{pH}, \mathrm{pH} 3$ 付近 まで，安定に存在することを見いだした（Table 2)。そこで molybdate 非存在にて $\left[{ }^{3} \mathrm{H}\right] \mathrm{MI}$ によ り標識した細胞質を0.5M KCl 条件にしたのちに 酸性化すると, pH 3 で DNA-cellulose に結合す

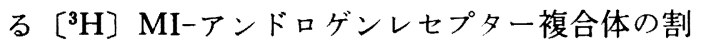
合は総結合の $67 \%$ 占め, $0.5 \mathrm{M} \mathrm{KCl}$ 処理した細 胞質 $(31 \%)$ の 2.2 倍であり，量的にも同様であっ た (Table 2)。この場合でも $\left[{ }^{3} \mathrm{H}\right] \mathrm{MI}$-アンドロ ゲンレセプター 複合体は沈澌していた。 $0.5 \mathrm{M}$ $\mathrm{KCl}$ 存在下と非存在下では条件が異なり，0.5M $\mathrm{KCl}$ 存在, 酸性条件下で起こる活性化が同様に $\mathrm{KCl}$ 非存在下でも起こるとは断定できない。し かしながら，酸沈澱から回収される $\left[{ }^{3} \mathrm{H}\right] \mathrm{MI}$ 結 合能や [ $\left.{ }^{3} \mathrm{H}\right] \mathrm{MI}$-アンドロゲンレセプター複合体 が molybdate 存在下ではより低い $\mathrm{pH}$ まで安定 であること, また, 中性条件にて形成された [ $\left.{ }^{3} \mathrm{H}\right] \mathrm{MI}$-アンドロゲンレセプター複合体も, 酸 性条件でその活性型が非活性型より, より不安定 ある事実 (Fig. 2b) は, $\mathrm{KCl}$ 非存在下においても 酸性条件（pH 4.9以下）でレセプターの活性化が 起こり，すみやかに活性型レセプターが変性する
ことを示唆している。

5. ラット前立腺アンドロゲンレセプター, 肝 臓グルココルチコイドレセプター，ならびに子宮 エストロゲンレセプターの酸性条件での安定性

これまでの結果はラット顎下腺アンドロゲンレ セプターが酸性条件でも比較的安定であることを 示している。そこで次に，このような性質が，顎 下腺アンドロゲンレセプターに特異的な現象かど うかを検討した。まずアンドロゲンの標的臟器と して最もよく研究されているラット前立腺アンド ロゲンレセプターについて検討した。Fig. 7 に示 すように，前立腺アンドロゲンレセプターの場合 は，その [ $\left.{ }^{3} \mathrm{H}\right] \mathrm{MI}$ 結合能は $\mathrm{pH} 6.4$ に半減する が，酸沈澱した細胞質タンパクを中性の緩衝液に 再溶解することにより，その結合能をほぼ完全に 回復した。肝藏グルココルチコイドレセプター, 子宮エストロゲンレセプターでも同様の結果が得 られた（Figs. 8，9)。ただしエストロゲンレセプ タ一の場合は, 酸性条件での $\left[{ }^{3} \mathrm{H}\right]$ エストラジオ 一ル結合能は比較的低 $\mathrm{pH}$ まで保たれ， $\mathrm{pH} 5.2$ で半減した。沈港については顎下腺アンドロゲン レセプターの場合と同様に，沈澱より回復する $\left[{ }^{3} \mathrm{H}\right]$ ステロイド結合能と 沈澱する $\left[{ }^{3} \mathrm{H}\right]$ ステロ イドーレセプター複合体の $\mathrm{pH}$ プロフィールはほ とんど同様のパターンを示した。沈澱より回収 される結合の最大量はほとんど 細胞質の結合量と 同程度であり，特にグルココルチコイドレセプタ 


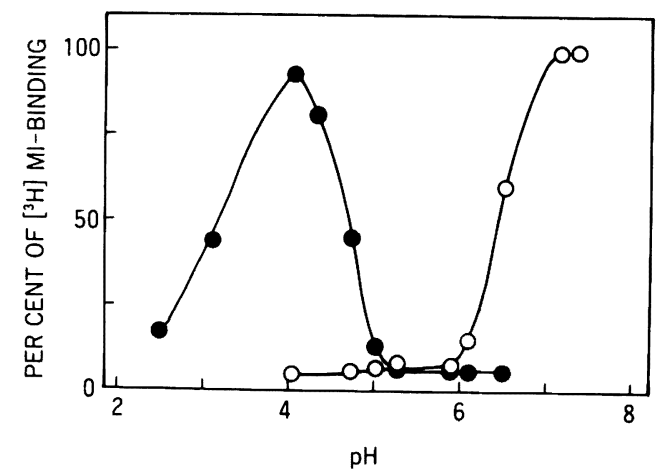

Fig. $7\left[{ }^{3} \mathrm{H}\right]$ MI-binding ability of rat prostate cytosol under acidic conditions. The cytosol from rat prostate in buffer B was acidified and two aliquots $(0.1 \mathrm{~m} l$ each) were withdrawn at various $\mathrm{pH}$ values. A series of the acidic cytosols were centrifuged at $6,000 \times \mathrm{g}$ for $10 \mathrm{~min}$ and the resulting precipitates were dissolved in $0.1 \mathrm{ml}$ of buffer B. The acidified cytosol (O) and the sample derived from the precipitae (•) at each $\mathrm{pH}$ level were then incubated with $\left[{ }^{3} \mathrm{H}\right] \mathrm{MI}$. After $4 \mathrm{~h}$, the samples were applied to HAP minicolumns and bound radioactiviy was counted. Results are expressed as per cent of the binding to that of the original cytosol $(4,908 \mathrm{dpm} / 0.1 \mathrm{~m} l)$.

一については $\mathrm{pH}$ 4.6の沈澱より回復する

TA 結合能は細胞質のそれを $26 \%$ 上回った（Fig. 8a)。同様の現象は実はすでに顎下腺 アンドロゲ ンレセプターでも見られている。すなわち Fig. 3b に示されたように，䫟下腺アンドロゲンレセプ ターでも $\mathrm{pH} 4.8$ の沈涮より回復する $\left[{ }^{3} \mathrm{H}\right] \mathrm{MI}$ 結合能は $53 \%$ であり，(細胞質の結合能を上回って

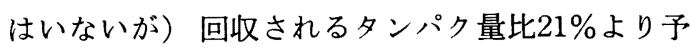
想される最大の結合 $(21 \%)$ より 2.5 倍も大きい。 この結果は, 細胞質が molybdate を含まない場 合，酸沈澱したタンパク質を molybdate を含む緩 衝液に溶解したために 細胞質とひとたび沈澱した 試料とで結合測定条件が 異なるために生じた差異 だと考えられた。例えば肝グルココルチコイドレ セプターの場合, 沈澱より回復する $\left[{ }^{3} \mathrm{H}\right] \mathrm{TA}$ 結 合能の最大值が, molybdate を含まない細胞質よ り通常20-50\%高值を示すが，その值は molybdate を含む細胞質の結合量とほとんど一致した (Table

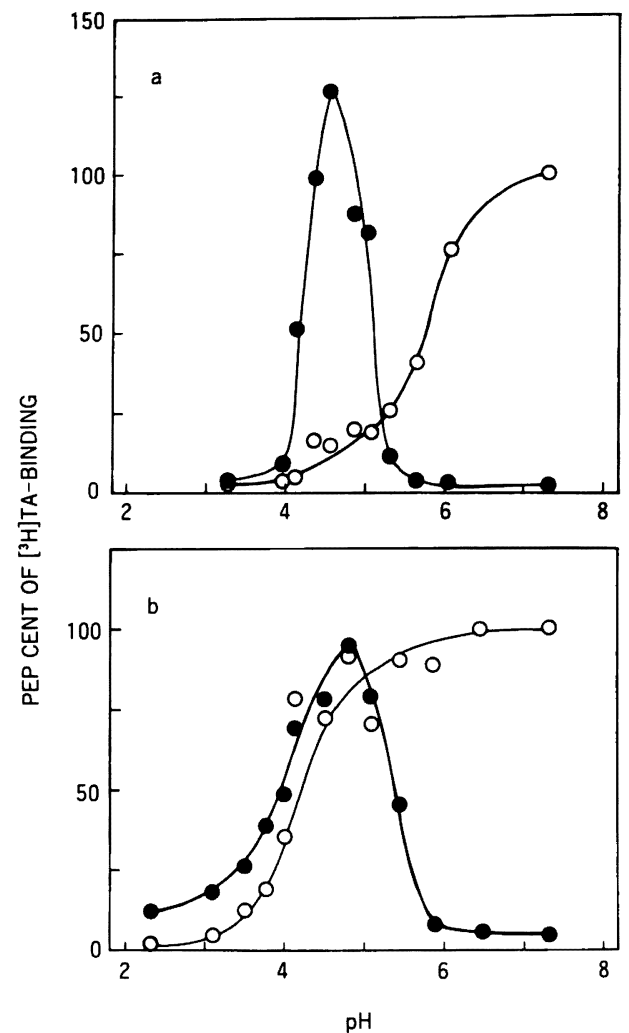

Fig. $8\left[{ }^{3} \mathrm{H}\right]$ TA-binding of rat liver cytosol under acidic conditions. (a) The cytosol in buffer A from rat liver was acidified and two aliquots $(0.1 \mathrm{~m} l)$ were withdrawn at various $\mathrm{pH}$ values. A series of samples were centrifuged and the precipitates obtained were dissolved in $0.1 \mathrm{ml}$ of buffer $B$. The acidic cytosols (O) and the samples from the precipitates (0) were incubated with $20 \mathrm{nM}\left[{ }^{3} \mathrm{H}\right] \mathrm{TA}$ for $5 \mathrm{~h}$ and the bindings were measured by HAP minicolumns. Results are indicated as per cent of the binding to that of the original cytosol $(12,100 \mathrm{dpm} / 0.1 \mathrm{ml})$. (b) Rat liver cytosol in buffer $A$ was incubated with $20 \mathrm{nM}\left[{ }^{3} \mathrm{H}\right] \mathrm{TA}$ for $5 \mathrm{~h}$ and free steroid was removed by the DCC method. Then, $\left.{ }^{3} \mathrm{H}\right]$ TA-labeled cytosol was acidified and two aliquots $(0.1 \mathrm{~m} l)$ were withdrawn at various $\mathrm{pH}$ values. After being kept for $5 \mathrm{~h}$, a series of samples were centrifuged at $6,000 \times \mathrm{g}$ for 10 $\mathrm{min}$, and the precipitates obtained were dissolved in $0.1 \mathrm{~m} l$ of buffer $B$. Thereafter, $\left[{ }^{3} \mathrm{H}\right]$ T A-labeled and acidified cytosol (O) and the precipitate dissolved in buffer B ( ) were applied to HAP minicolumns and the bindings were measured. Results are indicated as per cent of the binding to that of the original cytosol $(9,204 \mathrm{dpm} / 0.1 \mathrm{~m} l)$. 


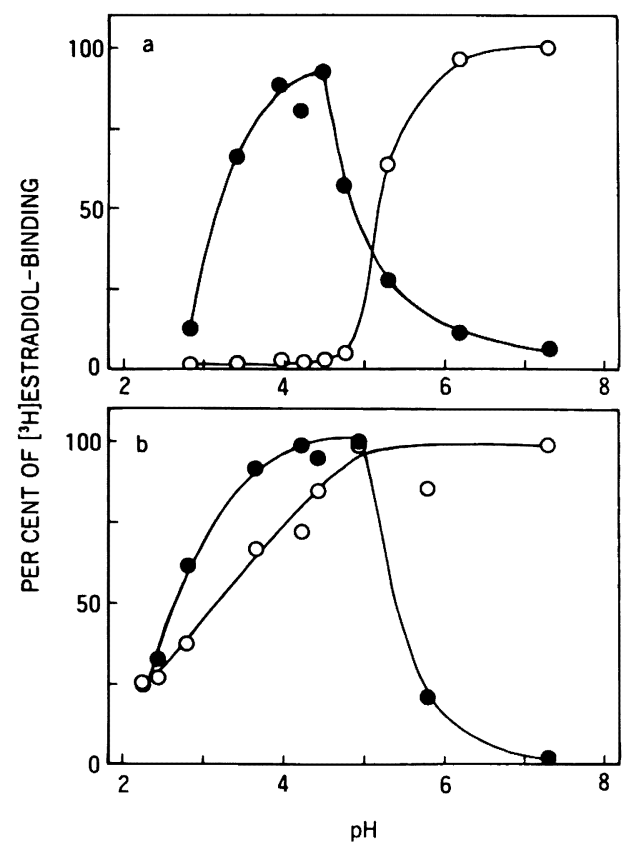

Fig. $9\left[{ }^{3} \mathrm{H}\right]$ Estradiol-binding of rat uterus cytosol under acidic conditions. ( $a$ and $b$ ) The same experiments in Fig. $8 a$ and $b$ were performed on rat uterine cytosol in buffer $\mathrm{A}$. The samples were incubated with $5 \mathrm{nM}\left[{ }^{3} \mathrm{H}\right]$ estradiol for $4 \mathrm{~h}$. Results are indicated as per cent of the binding to that of the original cytosols $(17,571$ $\mathrm{dpm} / 0.1 \mathrm{~m} l)$. Symbols are the same as those in Fig. 8.
3)。しかしながら酸沈測したタンパク質を molybdate を含まない緩衝液に溶解した場合には molybdate を含まない細胞質の結合より，少ない值し か得られず，このことは肝グルココルチコイドレ セプターよりも特に $\left[{ }^{3} \mathrm{H}\right]$ ステロイド結合容量の 低い䪽下腺アンドロダンレセプター9)について解 析する上には不利であった。そのため今回の全て の実験において，沈溉は molybdate を含む緩衝 液, すなわち buffer B にて溶解した。

Figs. 7-9 の結果は頼下腺アンドロゲンレセプ ターのみでなく, 前立腺アンドロゲンレセプタ 一, さらに他のステロイドレセプター, すくなく ともグルココルチコイドやエストロゲンレセプタ 一において, これらのレセプターが, 酸性条件で, これまで考えられてきたよりも安定であることを 示している。

\section{考察}

これまでアンドロゲンレセプターを含めステロ イドレセプターは $\mathrm{pH} 6$ 以下の酸性条件では変性 すると考えられてきた ${ }^{25,28,299}$ 。これは主に $\mathrm{pH} 6$ 以下でステロイドレセプターがリガンド結合能を 失うという事実によっている。また通常りガンド ーレセプター複合体の定量に用いられる DCC 法 では，遊離のリガンドをチャコールに吸着させ， 上清にリガンドーレセプター複合体を得る。その

Table 3 Effects of molybdate on the recovery of $\left[{ }^{3} \mathrm{H}\right]$ TA-binding ability of the glucocorticoid receptor in the acidic precipitate

\begin{tabular}{|c|c|c|c|c|c|}
\hline & \multirow{2}{*}{$\mathrm{pH}$} & \multicolumn{2}{|c|}{ Molybdate } & \multirow{2}{*}{\multicolumn{2}{|c|}{$\underset{(\mathrm{dpm})}{\left[{ }^{3} \mathrm{H}\right] \underset{\text { T }}{\mathrm{A}-\mathrm{binding}}}$}} \\
\hline & & $\begin{array}{c}\text { Original } \\
\text { buffer }\end{array}$ & $\begin{array}{l}\text { Buffer dissolving } \\
\text { precipitate }\end{array}$ & & \\
\hline \multirow[t]{2}{*}{ Cytosol } & \multirow[t]{2}{*}{7.3} & - & & \multicolumn{2}{|c|}{$9456 \pm 839^{a}(100.0 \pm 8.9)$} \\
\hline & & + & & \multicolumn{2}{|c|}{$11607 \pm 314^{\mathrm{a}}(122.7 \pm 3.3)$} \\
\hline \multirow[t]{4}{*}{ Precipitate } & 4.8 & - & - & 4638 & $(49.0)$ \\
\hline & & - & + & 11617 & (122.9) \\
\hline & 4.7 & - & - & 4190 & $(44.3)$ \\
\hline & & - & + & 11779 & (124.6) \\
\hline
\end{tabular}

a s. d.

Acid solutions were added to the rat liver cytosol in buffer $\mathrm{A}$ to adjust $\mathrm{pH}$ to 4.7-4.8. An aliquot $(0.1 \mathrm{ml})$ of the acidified cytosol was centrifuged and the precipitate obtained was dissolved in $0.1 \mathrm{ml}$ of buffer A (-molybdate) or B (+molybdate). The samples were incubated with $\left[{ }^{3} \mathrm{H}\right] \mathrm{TA}$ for $4 \mathrm{~h}$ and $\left[{ }^{3} \mathrm{H}\right]$ TA-binding was measured with HAP minicolumns. As a control, the cytosol prepared in buffer $A$ or $B$ was incubated with $\left[{ }^{8} \mathrm{H}\right]$ TA for $4 \mathrm{~h}$ and $\left[{ }^{3} \mathrm{H}\right]$ TA-binding was measured with a HAP minicolumn. 
State

$\mathrm{pH}$

Candidates of dissociable group

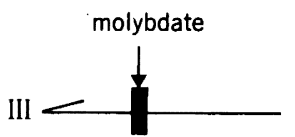

$\sim 4$
II

aspartic acid glutamic acid

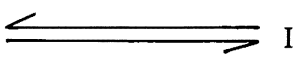

5.9

Fig. 10 Schematic model of the states of AR under acidic conditions.

State I: AR interacts with $\left[{ }^{3} \mathrm{H}\right] \mathrm{MI}$ and $\left[{ }^{3} \mathrm{H}\right] \mathrm{MI}-\mathrm{AR}$ complexes are stable.

State II : AR does not interact with $\left[{ }^{3} \mathrm{H}\right] \mathrm{MI}$, but once formed $\left[{ }^{3} \mathrm{H}\right] \mathrm{MI}-\mathrm{AR}$ complexes are stable.

State III : AR is transformed, and then, denatures irreversibly.

ため, 中性 $\mathrm{pH}$ においてリガンドとインキュベー ションした後に $\mathrm{pH}$ を下げた場合でも，リガンド ーレセプター複合体は沈澱するため DCC 法では 検出不可能であり, 結果として, ステロイドレセ プターは酸性条件ではリガンドを結合しないと考 えられてきたと思われる。この点, 今回用いたミ

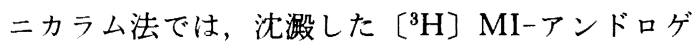
ンレセプター複合体も定量可能なので，酸性条件 でのレセプター分析に適しているといえる。

本研究はアンドロゲンレセプターは中性以下, $\mathrm{pH} 5.9$ と 4 付近において 2 段階の遷移過程と, それに応じた 3 種類の状態をとることを明らかに した（Fig．10)。第一の状態は中性から pH 5.9 までであり，この状態のアンドロゲンレセプタ 一は [ $\left.{ }^{3} \mathrm{H}\right] \mathrm{MI}$ 結合を有している。これまでの ほとんどのアンドロゲンレセプターの研究はこの 状態のレセプターに関するものである ${ }^{6-18)}$ 。第二 番目の状態は molybdate 非存在下では pH 5.9-4 付近までであり， molybdate 存在下ではより低い $\mathrm{pH}$ まで保たれる。アンドロゲンレセプターはこ の $\mathrm{pH}$ 領域において $\left[{ }^{3} \mathrm{H}\right] \mathrm{MI}$ 結合能は持たない が，ひとたび，中性条件で形成された [ $\left.{ }^{3} \mathrm{H}\right] \mathrm{MI}-$ アンドロゲンレセプター複合体は解離しない。ア ンドロゲンレセプターはこのうち，molybdate 非 存在下では $\mathrm{pH}$ 4.9をピークとして, molybdate 存在下ではより低い $\mathrm{pH}$ において沈澱するが, こ れは細胞質タンパク質の沈澱に存在する非特異的 現象であり，レセプターの本質的な性質とは無関 係であると思われる。一方，すでに村山と伊藤 ${ }^{30}$ はブタ子宮のエストロゲンレセプターについて同 様の検討をおこない, $\mathrm{pH} \mathrm{5-5.5でエストロゲンレ}$
セプターはリガンドを結合した状態で沈㴬し，上 清に回収されないために，これまで見かけ上結合 能を失うを考えられてきたと報告している。しか しながら，本報告の結果は，顎下腺アンドロゲン レセプターの $\mathrm{pH}$ 5.9での見かけのリガンド結合 能の衰失はレセプタータンパク質の沈澱とは無関 係の現象であることを示している。また前立腺ア ンドロゲンレセプター（Fig. 7）やグルココルチ コイドレセプター（Fig. 8a）でも pH 5-6の範囲 の $\left[{ }^{3} \mathrm{H}\right]$ ステロイド結合能は酸性化細胞質と沈澱 の両者を加えても細胞質の 結合能をかなり下回っ ている。このことはこれらのレセプターでも酸性 化条件での細胞質の見かけの結合能の喪失が，夕 ンパク質の沈澱とは無関係の現象であることを示 唆する。一方, エストロゲンレセプターについて は細胞質の $\left[{ }^{3} \mathrm{H}\right]$ エストラジオール結合能が比較 的低い $\mathrm{pH}$ まで安定なために，細胞質の結合能の 减少と沈澱より回復する結合能が見かけ上逆相関 寸るように見えるのではないかと思われる（Fig. 9a)。エストロゲンレセプターに関してはさらに 検討が必要であろう。

これまで，リガンド結合能のないステロイドレ セプターの存在を 示唆するいくつかの報告がなさ れている ${ }^{33,36-39 !}$ 。そのうちのいくつかの報告は, このような状態のレセプターが ATP 濃度や, 酸素分圧の低下により生じ，これらの条件を復帰 することによりリガンド結合能が 回復すると報告 している36,371。しかしながらアンドロゲンレセプ ターに関して可逆的に 結合能を失った状態が存在 しうることを明らかにしたのは著者の知る限り本 論文が最初である。実際にin vivoにおいてもリ 
ガンド結合能のないアンドロゲンレセプターが存 在するのかどうかは，興味深いところであり，今 後重要な問題である。

アンドロゲンレセプターが $\mathrm{pH}$ に依存して可逆 的にリガンド結合能を失う現象を説明する最もあ りそうな可能性は, $\left[{ }^{3} \mathrm{H}\right] \mathrm{MI}$ の結合に必須の pK 5.9 のアミノ酸残基が，おそらくアンドロゲン レセプターのリガンド結合部位，またはその近傍 に存在する，しかしながらこのアミノ酸残基はひ とたび結合した $\left[{ }^{2} \mathrm{H}\right] \mathrm{MI}$ を結合した状態のま ま保つには必要ではないというものである。この 付近に $\mathrm{pK}$ をもつアミノ酸は唯一七スチジンだけ であり，またヒスチジンはその $\mathrm{pK}$ 以下ではプロ トン化して極性を増すが，それがきわめて非極性 の分子であるステロイドの結合を妨げるのかもし れない。

第三の状態への変化，つまりアンドロゲンレセ プターの変性は $\mathrm{pH} 4.9$ 以下主に $\mathrm{pH} 4.1$ 付近でお こる。この変換過程は molybdate 依存性である。 それはこの過程が, 実際にはレセプターの活性化 とそれに引き続く活性型レセプターの酸変性とい う二つの段階からなることをつよく示唆する。実 際, molybdate 非存在, $0.5 \mathrm{M} \mathrm{KCl}$ 存在下では酸 性条件でのアンドロゲンレセプターの活性化が認 められたが，塩非存在下では明確な結果は得られ なかった。これはこの条件で生ずる活性型アンド ロゲンレセプターが，非常に不安定なためと思わ れる。

本研究はラット顎下腺 アンドロゲンレセプター のみではなく， 前立腺アンドロゲンレセプター,
肝臟グルココルチコイドレセプターさらに子宮エ ストロゲンレセプターも，酸性条件においてかな り安定であることを示した。ただし，アンドロゲ ンとグルココルチコイドレセプターが共に $\mathrm{pH}$ 5.9 付近で見かけのリガンド結合能が半減するの に対し,エストロゲンレセプターではほぼ $\mathrm{pH} 5.2$ で結合能は半減した。このことはエストロゲンレ セプターが他のステロイドレセプターよりも加温 処理などにも比較的安定である事実 ${ }^{401}$ との関連を 思わせる。しかしながら Hansen と Gorski28) は 同じラット子宮エストロゲンレセプターのリガン ド結合能は $\mathrm{pH} 5.8$ で半減すると報告しているの でこの点については，さらに検討する必要があろ う。いずれにしろアンドロゲン，グルココルチコ イド，ならびにエストロゲンレセプターが酸性条 件において, やや状態変化する $\mathrm{pH}$ が異なる可能 性はあるにしろ，どれもよく似た性質を示すこと は，一見，理解しにくいことである。しかしなが ら，これらのレセプターは，そのステロイド結合 の特異性以外にはこれまでに知られている物理化 学的性質がきわめて類似することから考えるとむ しろ当然なのかも知れない。また本研究の結果は さらに他のステロイドレセプターつまりプロゲス テロン, ミネラルコルチコイド, ビタミン $\mathrm{D}_{3} レ$ セプターなどについても，同様に酸性条件での安 定性の再検討の必要性を示している。

謝辞：御指導ならびに御校閲在睗りました岩手医科大 学歯学部口腔生化学講座太田稔教授に感謝いたします。 また終始直接実験の指導を賜り，かつ有益な御助言をい ただいた根本孝幸講師に感謝いたします。

抄録：ラット顎下腺アンドロゲンレセプターの酸性条件において合成アンドロゲンである〔 $\left.{ }^{3} \mathrm{H}\right]$ miborelone $\left(\left[{ }^{3} \mathrm{H}\right] \mathrm{MI}\right)$ 結合活性を検討した。10mM molybdate 存在下, 非存在下とも [ $\left.{ }^{3} \mathrm{H}\right] \mathrm{MI}$ 結合活性は $\mathrm{pH}$ 5.9で半減した。この結合活性の波失は, 酸沈使した細胞質タンパク質を中性の緩衝液に再溶解することによ り回復した。Molybdate 存在下では結合活性の回復は, 沈澱のタンパク量に一致したが, molybdate 非存在 下では沈波より回復する結合活性は $\mathrm{pH} 4.9$ において最大值を示し，それ以降は急速に減少した。一方，molybdate を含まない細胞質をまず $\left[{ }^{3} \mathrm{H}\right] \mathrm{MI}$ により標識しその後に $\mathrm{pH}$ を下げた場合には中性条件で形成され た $\left[{ }^{3} \mathrm{H}\right] \mathrm{MI}$-アンドロゲンレセプター複合体はより安定であり，pH 4.2にて半減した。Molybdate 存在下で は複合体はさらに低い $\mathrm{pH}$ まで安定であった。Molybdate 存在下, 非存在下とも $\left[{ }^{3} \mathrm{H}\right] \mathrm{MI}$-アンドロゲンレ セプター複合体は $\left[{ }^{3} \mathrm{H}\right] \mathrm{MI}$ 非存在下と同様に沈澱した。これらの結果はアンドロゲンレセプターが $\mathrm{pH}$ 4.1-5.9ではその $\left.{ }^{3} \mathrm{H}\right] \mathrm{MI}$ 結合活性について特殊な状態にあることを示唆している。すなわち，この領域で はアンドロゲンレセプターはリガンド結合活性はないが，あらかじめ $\left[{ }^{3} \mathrm{H}\right] \mathrm{MI}$ が結合している場合は, 酸性 化によりたとえレセプターが沈溊してもこのリガンドは保持される。さらにアンドロゲンレセプターは $\mathrm{pH}$ 
5 以下で真の変性がおこり, $\mathrm{pH} 4.1$ でその $1 / 2$ 変性する。この変性過程は, 酸性条件でのアンドロゲンレ セプターの活性化と，ひきつづき起こる活性型レセプターの変性よりなると考えられた。

\section{References}

1) Lacassegne, A.: Dimorphisme sexual de la glande sous-maxillaire chez ls souris. Comp. Rend. Soc. Biol. 133 : 180-181, 1940.

2) Caramia, F., Angeletti, P. U. and Levi-Montalcini, R. : Experimental analysis of the mouse submandibular gland in relationship to its nerve-growth factor content. Endocrinology 70 : 915-922, 1962.

3) Byyny, R. L., Orth, D. N. and Cohen, S. : Radioimmunoassay of epidermal growth factor. Endocrinology 90:1261-1266, 1972.

4) Angeletti, R. A., Angeletti, P. U. and Calissano, P.: Testosterone induction of esteroproteolytic activity in the mouse submaxillary gland. Biochim. Biophys. Acta 139 : 372-381, 1967.

5) Jensen, E. V., Suzuki, T., Numata, M., Smith, S. and DeSombre, E. R. : Estrogenbinding substances of target tissues. Proc. Natl. Acad. Sci. USA. 59 : 632-638, 1968.

6) Wilson, J. D. and Goldstein, J. L. : Evidence for increased cytoplasmic androgen binding in the submandibular gland of the mouse with testicular feminization. J. Biol. Chem. 247 : 7342-7348, 1972.

7) Verhoeven, G.: Androgen binding protein in the mouse submandibular gland. J. Steroid Biochem. 10 : 121-133, 1979.

8) Sato, N., Nemoto, T., Baba, R. and Ota, M. : Dialysis induced transformation of mouse submandibular androgen receptor. Biochem. Int. $10: 771-766,1985$.

9) Nemoto, T., Ohara-Nemoto, Y., Sato, N., Kyakumoto, S. and Ota, M. : Characterization of nontransformed and transformed androgen receptor from rat submandibular gland. Biochim. Biophys. Acta 839 : 249257, 1985.

10) Ohara-Nemoto, Y., Nemoto, T., Sato, N., Kyakumoto, S. and Ota, M. : Comparison of androgen receptor in male and female rat submandibular glands. Jpn. J. Oral Biol. 27 : 679-684, 1985.

11) Kyakumoto, S., Kurokawa, R., OharaNemoto, Y. and Ota, M. : Sex difference in the cytosolic and nuclear distribution of androgen receptor in mouse submandibular gland. J. Endocrinol. 108 : 267-273, 1986.

12) Kyakumoto, S., Kurokawa, R. and Ota, M. : Effect of castration and administration of testosterone on cytosol and nuclear an- drogen receptor in mouse submandibular gland. Biochem. Int. 11 : 701-707, 1985.

13) Sato, N, Nemoto, T., Ohara-Nemoto, Y., Baba, R. and Ota, M. : Effects of castration and sex hormones on the androgen receptor of the mouse submandibular gland. Jpn. J. Oral Biol. 27 : 640-648, 1985.

14) Verhoeven, G. and Wilson, J. D. : Cytosol androgen binding in submandibular gland and kidney of the normal mouse and the mouse with testicular feminization. Endocrinology 99 : 79-92, 1976.

15) Sato, N., Ohara-Nemoto, Y. and Ota, M. : Transformation of androgen receptor from mouse submandibular glands by gel chromatography. J. Endocrinol. 108 : 123-127, 1986.

16) Mainwaring, W. I. P. and Irving, R. : The use of of DNA cellulose chromatography and isoelectric focusing for the characterization and partial purification of steroid-receptor complexes. Biochem. J. 134 : 113-127, 1973.

17) Fang, S. and Liao, S. : Androgen receptors : steroid and tissue specific retention of 17 $\beta$-hydroxy- $5 \alpha$-androstan-3-one-protein complex by the cell nuclei of ventral prostate. J.Biol. Chem. 246 : 16-24, 1971.

18) Lin, S.-Y. and Ohno, S.: The binding of androgen receptor to DNA and RNA. Biochim. Biophys. Acta 654 : 181-186, 1981.

19) Kovacs, W. J., Griffin, J. E. and Wilson J. D. : Transformation of human androgen receptor to the deoxyribonucleic acid-binding state. Endocrinology 113 : 1574-1581, 1983.

20) Shrader, W. T., Toft, D. O. and O'Malley, B. W. : Progesteronebinding protein of chick oviduct. VI. Interaction of purified progesterone receptor components with nuclear components. : J. Biol. Chem. 247 : 24012407, 1972.

21) Milgrom, E., Atger, M. and Baulieu, E. E. : Acidophilic activation of steroid hormone receptors. Biochemistry $12: 5198$ 5295, 1973.

22) Holbrook, N. J., Bodwell, J. E., Jeffries, M. and Munck, A.: Characterization of nonactivated and activated glucocorticoid receptor-complexes from intact rat thymus cells. J. Biol. Chem. 258 : 6477-6485, 1983.

23) Vedeckis, W. V.: Subunit dissociation as a possible mechanism of glucocorticoid receptor activation. Biochemistry 22 : 1983-1989, 1983.

24) Sherman, M. R., Moran, M. C., Tauzon, 
F. B. and Setvens, Y.-W.: Structure, dissociation, and proteolysis of mammalian steroid receptors. J. Biol. Chem. 258 : 1036610377, 1983.

25) Bailly, A., Savouret, J.-F., Sallas, N. and Milgrom, E. : Factors modifying the equilibrium between activated and non-activated forms of steroid-receptor complexes. Eur. J. Biochem. 88 : 623-632, 1978.

26) Bodine, P. V., Schmidt, T. J. and Litwack, G.: Evidence that $\mathrm{pH}$ induced activation of the rat hepatic glucocorticoid-receptor complex is irreversible. J. steroid Biochem. 20 : 683-689, 1984.

27) Wilson, E. M. : Interconversion of androgen receptor forms by divalent cations and $8 \mathrm{~S}$ androgen receptor-promoting factor. J. Biol. Chem. 260 : 8683-8689, 1985.

28) Hansen, J. C. and Gorski, J. : Conformational and electrostatic properties of unoccupied and liganded estrogen receptors determined by aqueous two-phase partitioning. Biochemistry 24 : 6078-6085, 1985.

29) Wright, W. W., Chan, K. C. and Bardin, C. W.: Characterization of the stabilizing effect of sodium molybdate on the androgen receptor present in mouse kidney. Endocrinology 108 : 2210-2216, 1981.

30）村山 昭, 伊藤孝司：エストロゲンレセプター の酸沈湃 生化学 $58: 973,1986$.

31) Holbrook, N. J., Bodwell, J. E. and Munck, A. : Effects of ATP and pyrophosphate on properties of glucocorticoid-receptor complexes from rat thymus cells. J. Biol. Chem. 258 : 14885-14894, 1983.

32) Bradford, M. M. : A rapid and sensitive method for the quantitation of microgram quantities of protein utilizing the principle of protein-dye binding. Anal. Biochem. 72 :
248-254, 1976.

33) Nielsen, C. J., Sando, J. J., Vogel, W. M. and Pratt, W. B.: Glucocorticoid receptor inactivation under cell-free conditions. J. Biol. Chem. 252 : 7568-7578, 1977.

34) Nishigori, H. and Toft, D.: Inhibition of progesterone receptor activation by sodium molybdate. Biochemistry 19 : 77-83, 1980.

35) Noma, K., Nakao, K., Sato, B., Nishizawa, Y., Matsumoto, K. and Yamamura, Y. : Effect of molybdate on activation and stabilization of steroid receptors. Endocrinology 107 : 1205-1211, 1980.

36) Bell, P. A. and Munck, A. : Steroid-binding properties and stabilization of cytoplasmic glucocorticoid receptors from rat thymus cells. Biochem. J. $136: 97-107,1973$.

37) Housley, P. R., Grippo, J. F., Dahmer, M. K. and Pratt, W. B. : Inactivation, activation, and stabilization of glucocorticoid receptors. in Biochemical Actions of Hormones (Litwack, G., ed) Vol. XI, pp 347-376, Academic Press, New York 1984.

38) Nakao, M., Sato, B., Koga, M., Noma, K., Kishimoto, S. and Matsumoto, K. : Identification of immunoassayable estrogen receptor lacking hormone binding ability in tamoxifen-treated rat uterus. Biochem. Biophys. Res. Commun. 132 : 336-342, 1985.

39) Mendel, D. B., Bodwell, J. E. and Munck, A. : Glucocorticoid receptors lacking hormone-binding activity are bound in nuclei of ATP-depleted cells. Nature 324 : 478-480, 1986.

40) Notides, C. A. and Nielsen, S. : The molecular mechanism of the in vitro $4 \mathrm{~S}$ to $5 \mathrm{~S}$ transformation of the uterine estrogen receptor. J. Biol. Chem. 249 : 1866-1873, 1974. 